\title{
Optimasi Tata Letak Fasilitas Menggunakan Algoritma Blocplan dan Corelap
}

\section{The Layout Optimization Using Blocplan and Corelap Algorithms}

\author{
Nabila Aulia Gunanti1), Ade Momon S.2), Dene Herwanto3), Jauhari Arifin4) \\ Program Studi Teknik Industri, Fakultas Teknik. Universitas Singaperbangsa Karawang \\ Diterima: Juli 2021; Disetujui: November 2021; Dipublikasi: November 2021; \\ *Coresponding author : nabila.aulia17129@student.unsika.ac.id
}

\begin{abstract}
Abstrak
Anni Bakery \& Cake merupakan salah satu UKM di Kabupaten Karawang yang bergerak di bidang produksi roti. Tata letak pabrik Anni Bakery \& Cake saat ini belum tertata dengan baik. Hal ini terlihat dari adanya cross movement, laju backtracking dan adanya ruang kosong yang tidak terpakai. Penelitian ini bertujuan untuk merancang ulang tata letak untuk mengoptimalkan bangunan saat ini. Penelitian ini menggunakan algoritma BLOCPLAN dan CORELAP. Dari kedua algoritma tersebut, tata letak yang optimal akan dipilih sebagai tata letak usulan berdasarkan nilai total momen perpindahan yang lebih rendah, ongkos material handling yang lebih rendah, dan nilai efisiensi tata letak yang lebih tinggi. Hasil penelitian menunjukkan bahwa CORELAP dipilih sebagai tata letak yang diusulkan karena kemampuannya menghasilkan performa yang optimal. CORELAP memberikan pengurangan momen perpindahan sebesar 3.012,34 m/hari, efisiensi tata letak sebesar 36,10\%, dan pengurangan $\mathrm{OMH}$ sebesar Rp. 18.626/hari.
\end{abstract}

Kata Kunci : Tata letak fasilitas; OMH; momen perpindahan material; BLOCPLAN; CORELAP

Abstract

Anni Bakery \& Cake is one of the SMEs in the field of bread production located in Karawang regency, Indonesia. The existing plant layout of the Anni Bakery \& Cake have not been arranged properly. It can be seen from the presence of a cross movement, backtracking flow and the presence of unused spaces. This study aims to re-design the layout to optimize the current building. This study uses BLOCPLAN and CORELAP algorithms. Of these two algorithms, the optimal layout will be chosen as the proposed layout based on aspects of the lower moment of material displacement, the lower material handling cost, and the higher percentage of layout efficiency. The results showed that CORELAP is chosen as the proposed layout because of its ability to offer optimal performance for the system. CORELAP provide a reduction in moments of material displacement of 3,012.34 m/day, improvement in layout efficiency of 36,10\%, and a reduction in material handling cost of Rp. 18.626/day.

Keywords : facility layout; material handling cost; moment of material displacement; BLOCPLAN; CORELAP

How to Cite: : Gunanti, N.A, Ade Momon S dkk (2021), Optimasi Tata Letak Fasilitas Menggunakan Algoritma Blocplan dan Corelap. JIME (Journal of Industrial and Manufacture Engineering). 5(2): 107 120 


\section{PENDAHULUAN}

Pengaturan tata letak produksi dapat berpengaruh terhadap produktivitas karyawan (Sutrisno, 2017). Tata letak fasilitas produksi yang baik ditandai dengan tidak adanya aliran balik (backtracking), frekuensi perpindahan minimum, dan tidak terjadinya antrean berlebih (bottleneck) (Setiyawan et al., 2017). Perancangan tata letak produksi yang baik harus mampu meningkatkan keefektifan dan keefisienan melalui penurunan jarak perpindahan material, dan Ongkos material handling (OMH) (Setiyawan et al., 2017).

Anni Bakery \& Cake merupakan salah satu UKM yang bergerak di bidang produksi roti. Saat ini kondisi tata letak fasilitas di Anni Bakery \& Cake mengalami kendala dalam hal penataan yang kurang efisien seperti yang ditunjukkan pada Gambar 1. Pada proses produksinya terdapat aliran pemindahan material yang berpotongan (cross movement) dikarenakan tidak adanya marka penanda gang antar stasiun kerja sehingga seringkali menghambat aliran pekerjaan, mengganggu pergerakan operator, dan menimbulkan rasa tidak nyaman. Selain itu jarak perpindahan material yang cukup jauh pada stasiun kerja pemanggangan ke stasiun kerja pengelupasan roti tawar menimbulkan $\mathrm{OMH}$ yang cukup besar, serta adanya aliran backtracking pada proses pengelupasan roti tawar ke proses pengemasan roti tawar. Ditemukan juga adanya hambatan keluar-masuk di pintu utama pabrik karena terhalang oleh bakery trolley pada proses pendinginan.

permasalahan Selain kendala yang telah disebutkan di atas, fasilitas pegawai berupa toilet belum tersedia pada tata letak saat ini. Pegawai/operator produksi yang ingin ke toilet harus berjalan kurang lebih 50 meter ke tempat tinggalnya masing-masing (yang difasilitasi oleh pemilik usaha).

Maka dari itu perlu dilakukan evaluasi terhadap tata letak pabrik Anni Bakery \& Cake dengan menghitung momen perpindahan, dan $\mathrm{OMH}$ yang ditimbulkan akibat tata letak saat ini, dan dirancang tata letak usulan yang memiliki momen perpindahan minimum dan $\mathrm{OMH}$ minimum. Untuk mencari tata letak usulan, pada penelitian ini digunakan algoritma Block Layout Overview with Layout Planning (BLOCPLAN) dan Computerized Relationship Layout Planning (CORELAP).

Beberapa penelitian terdahulu yang menggunakan algoritma BLOCPLAN antara lain: Susetyo et al. (2010), Siregar et al. (2013), Afridasani (2014), Gunawan et al. (2015), Richardo et al. (2017), dan Tambunan et al. (2018). Adapun beberapa penelitian yang menggunakan algoritma CORELAP yaitu: Langgihadi et al. (2016), Dwianto et al. (2016), Putra (2018), (Febianti et al., 2020), dan (Adiyanto \& Clistia, 2020). Tahapan pengolahan data pada penelitian ini mengadaptasi penelitian terdahulu. Namun yang membedakannya, pada penelitian terdahulu data masukan pada program BLOCPLAN dan CORELAP didapatkan dari luas fasilitas yang sama dengan tata letak awal.

ini dilakukan perhitungan kebutuhan luas ruangan atau fasilitas dengan menambahkan persentase kelonggaran untuk dijadikan data masukan pada program BLOCPLAN maupun CORELAP, sehingga luas setiap fasilitas dapat berbeda dari luas fasilitas pada tata letak awal. Sedangkan pada penelitian terdahulu, 
Tujuan utama pada penelitian ini yaitu untuk memperoleh rancangan tata letak pabrik Anni Bakery \& Cake yang lebih efektif dan efisien dengan mengoptimalkan luas bangunan dan sumber daya yang tersedia.

\section{METODE PENELITIAN}

Alur penelitian ditunjukkan pada Gambar 2.

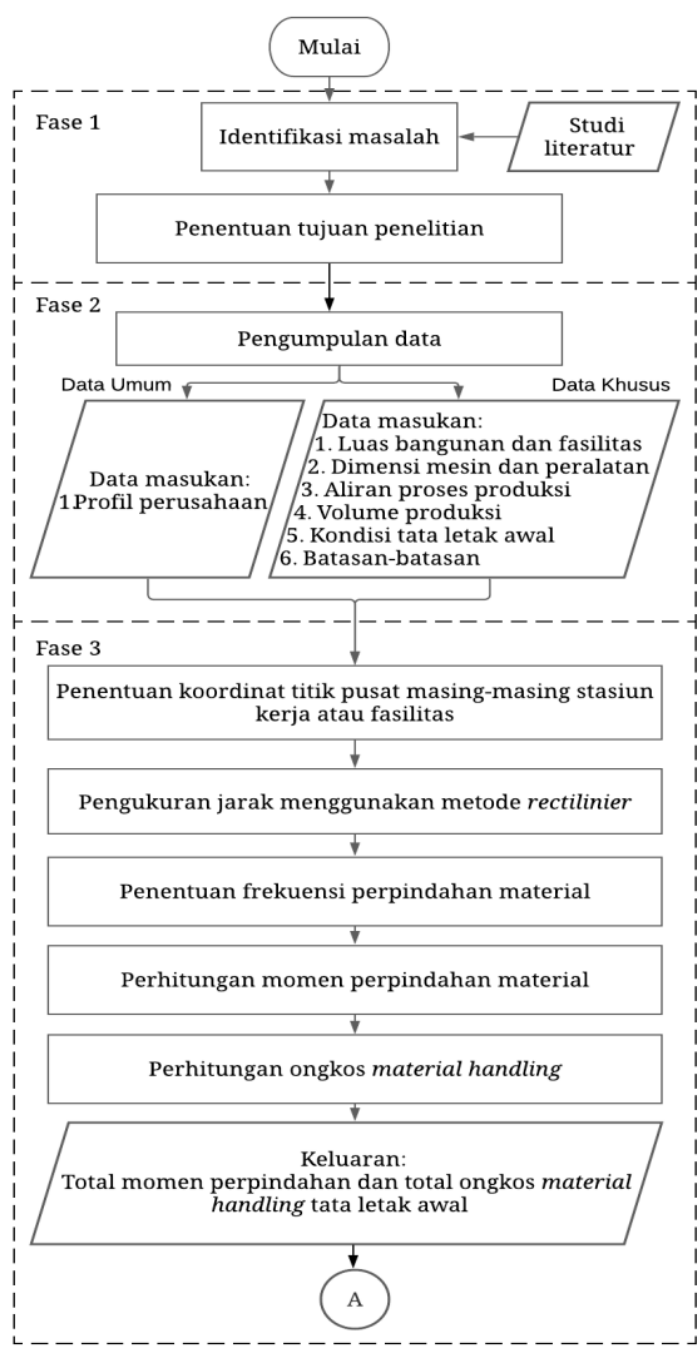

Gambar 1. Diagram Alir

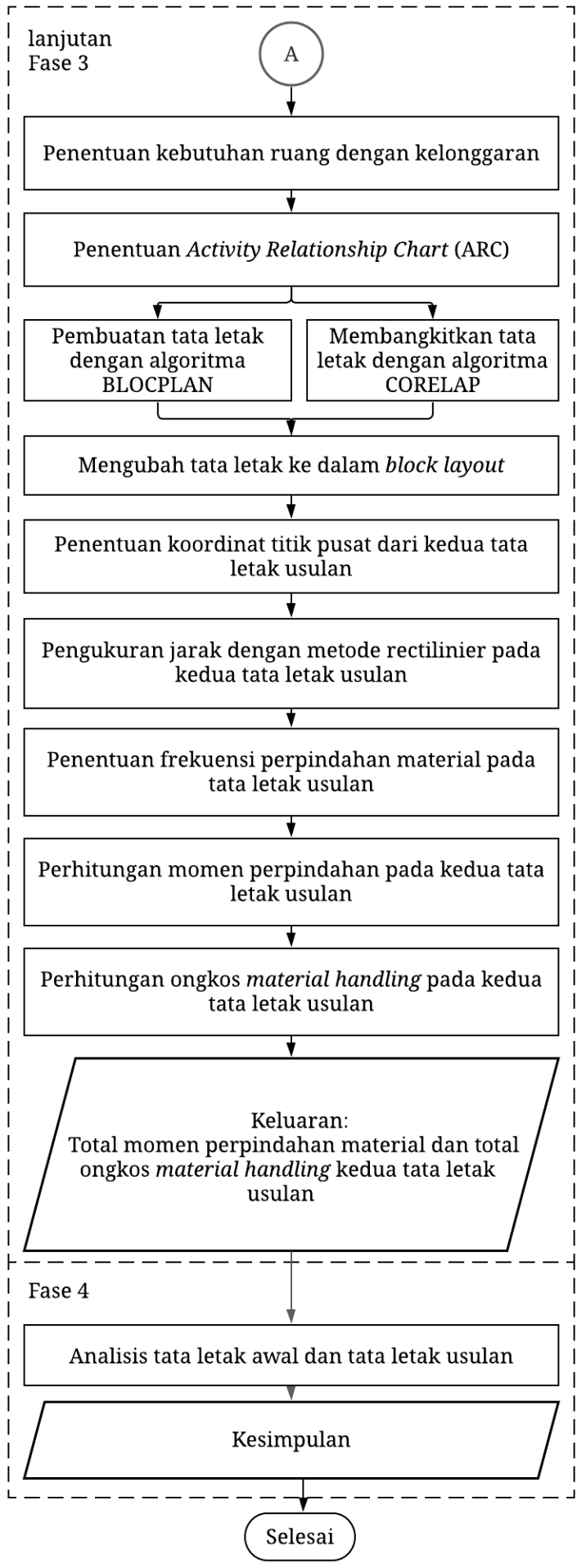

Gambar 2. Diagram Alir

Sumber: (Adiyanto \& Clistia, 2020), (Siregar et al., 2013) dimodifikasi

\section{Penentuan Titik Pusat Fasilitas}

Persamaan penentuan titik pusat $(\mathrm{x}, \mathrm{y})$ pada setiap fasilitas yang berbentuk 
persegi adalah sebagai berikut (Tarigan et al., 2017):

Koordinat $x=x_{0}+\frac{\left(x_{1}-x_{0}\right)}{2}$

Koordinat $y=y_{0}+\frac{\left(y_{1}-y_{0}\right)}{2}$

Adapun untuk fasilitas yang berbentuk non persegi, penentuan titik pusatnya dilakukan dengan membagi bentuk stasiun kerja tersebut menjadi bentuk persegi, kemudian digunakan rumus sebagai berikut:

Koordinat $X=T B_{x}=\frac{M_{x}}{L_{x}}=\frac{\sum X_{i} L_{i}}{\sum L_{i}}$

Koordinat $Y=T B_{y}=\frac{M_{y}}{L_{y}}=\frac{\sum Y_{i} L_{i}}{\sum L_{i}}$

Dimana $T B$ yaitu titik berat, $M$ yaitu momen, $L$ yaitu luas (Ignasius, 2017).

\section{Pengukuran Jarak Rectilinear}

Pada perhitungan jarak antar fasilitas diukur menggunakan jarak rectilinear, dengan rumus sebagai berikut (Iskandar \& Fahin, 2017):

$$
d_{i j}=\left|x_{i}-x_{j}\right|+\left|y_{i}-y_{j}\right|
$$

Dimana $d_{i j}$ merupakan jarak antara fasilitas $i$ ke fasilitas $j$.

\section{Perhitungan Momen Perpindahan}

Secara matematis, momen perpindahan dirumuskan sebagai berikut:

$$
M=f_{i j} \times d_{i j}
$$

Dimana $M$ merupakan momen perpindahan, dan $f_{i j}$ merupakan frekuensi perpindahan dari fasilitas $i$ ke fasilitas $j$.

\section{Perhitungan OMH Metode MOST}

Metode Maynard Operation Sequence Technique (MOST) dapat dijadikan acuan dalam penentuan lamanya waktu perjalanan operator pada jenis material handling manual (tenaga manusia) (detik/m). Kemudian nilainya dikalikan dengan biaya upah operator yang telah dikonversi ke dalam satuan $\mathrm{Rp} /$ detik, sehingga diperoleh $\mathrm{OMH} /$ meter. Nilai $\mathrm{OMH} / \mathrm{m}$ dikalikan dengan momen perpindahan (m) untuk diperoleh $\mathrm{OMH}$ (Rp).

$$
\begin{aligned}
& t=\frac{\text { Bil. index MOST } \times 10}{0,036 \text { detik }} \\
& P=\frac{\text { Upah operator }}{\text { Waktu kerja }} \\
& \text { OMH per meter }=P \times t \\
& O M H=M \times O M H \text { per meter }
\end{aligned}
$$

Dimana $t$ merupakan waktu perjalanan, dan $P$ merupakan biaya operator.

\section{Penentuan Kebutuhan Luas Lantai}

Dalam menentukan kebutuhan luas fasilitas yang optimal diukur dimensi mesin atau peralatan. Kemudian panjang maksimum mesin tiap fasilitas (ruang) dikalikan 1,00 $\mathrm{m}$ untuk tempat kerja operator, dan ditotal dengan panjang mesin. Nilainya dikalikan dengan 150\% untuk kelonggaran. Kelonggaran ini diperuntukkan bagi ruangan untuk pemindahan bahan, gerakan pegawai, tiang, ruang kerja yang dipergunakan gang, dan sebagainya (Apple, 2016).

\section{Pembentukan ARC}

Pada penelitian ini penentuan ARC dimodifikasi berdasarkan data kuantitatif dari besarnya frekuensi aliran perpindahan material antar fasilitas yang kemudian dikonversi menjadi nilai kedekatan kualitatif ARC. Nilai tertinggi frekuensi perpindahan dikurangi dengan nilai terendah frekuensi perpindahan lalu dibagi 3, dan dibuat rentang atas (untuk 
sandi kedekatan A), rentang tengah (untuk sandi kedekatan E), dan rentang bawah (untuk sandi kedekatan I). Sandi O digunakan untuk fasilitas yang tidak memiliki hubungan keterkaitan langsung terhadap stasiun kerja lainnya. Adapun sandi X ditentukan untuk keterkaitan fasilitas yang dapat mengganggu pergerakan pegawai atau keselamatan pegawai.

Tabel 1. Sandi Kedekatan ARC

\begin{tabular}{cl}
\hline Kode & \multicolumn{1}{c}{ Deskripsi } \\
\hline A & Mutlak perlu didekatkan \\
E & Sangat penting untuk didekatkan \\
I & Penting untuk didekatkan \\
O & Kedekatan biasa \\
U & Tidak penting untuk didekatkan \\
X & Tidak diharapkan didekatkan \\
\hline
\end{tabular}

Sumber Tabel: (Apple, 2016)

Tabel 2. Alasan Kedekatan ARC

\begin{tabular}{cl}
\hline Kode & \multicolumn{1}{c}{ Alasan } \\
\hline 1 & Urutan aliran kerja \\
2 & Menggunakan pegawai yang sama \\
3 & Gangguan pegawai \\
\hline
\end{tabular}

Sumber Tabel: (Apple, 2016) dimodifikasi

Tabel 3. Nilai Bobot Sandi Kedekatan

\begin{tabular}{cc}
\hline Kode & Nilai bobot \\
\hline A & 32 \\
E & 16 \\
I & 8 \\
O & 4 \\
U & 2 \\
X & 1
\end{tabular}

Sumber Tabel: (Heragu, 2006)

\section{Algoritma BLOCPLAN}

Konsep algoritma BLOCPLAN yaitu mengembangkan tata letak dengan menukarkan posisi fasilitas secara acak, dan menampilkan hasilnya beserta nilai adjacency score (nilai kedekatan antar fasilitas), $R$-score (efisiensi tata letak), dan rel-dist score (total jarak tempuh).

\section{Algoritma CORELAP}

CORELAP mengembangkan tata letak dengan mendahulukan fasilitas yang paling sibuk atau yang memiliki keterkaitan terbanyak berdasarkan nilai Total Closeness Rating (TCR).

\section{HASIL DAN PEMBAHASAN}

Luas bangunan pabrik Anni Bakery \& Cake sebesar 230,85 $\mathrm{m}^{2}$. Kondisi tata letak awal ditunjukkan pada Gambar 3.

\section{Frekuensi Perpindahan Awal}

Frekuensi perpindahan material per hari pada tata letak awal dapat dilihat pada Tabel 4.

Tabel 4. Frekuensi Perpindahan Awal

\begin{tabular}{|c|c|c|c|}
\hline No & Stasiun Awal & Stasiun Tujuan & Freq. \\
\hline 1 & $\begin{array}{l}\text { Gudang bahan } \\
\text { baku }\end{array}$ & Mixing & 13 \\
\hline 2 & $\begin{array}{l}\text { Gudang bahan } \\
\text { baku }\end{array}$ & $\begin{array}{l}\text { Pembentukan } \\
\text { roti manis }\end{array}$ & 5 \\
\hline 3 & $\begin{array}{l}\text { Area } \\
\text { penyimpanan } \\
\text { tepung }\end{array}$ & Mixing & 25 \\
\hline 4 & Mixing & Dough dividing & 54 \\
\hline 5 & Mixing & $\begin{array}{l}\text { Fermentasi } \\
\text { roti tawar }\end{array}$ & 22 \\
\hline 6 & Mixing & $\begin{array}{l}\text { Pembentukan } \\
\text { roti manis }\end{array}$ & 230 \\
\hline 7 & $\begin{array}{l}\text { Pembentukan } \\
\text { roti manis }\end{array}$ & $\begin{array}{l}\text { Fermentasi } \\
\text { roti manis }\end{array}$ & 160 \\
\hline 8 & $\begin{array}{l}\text { Fermentasi } \\
\text { roti tawar }\end{array}$ & $\begin{array}{l}\text { Pembentukan } \\
\text { roti tawar }\end{array}$ & 22 \\
\hline 9 & $\begin{array}{l}\text { Pembentukan } \\
\text { roti tawar }\end{array}$ & $\begin{array}{l}\text { Fermentasi } \\
\text { roti tawar }\end{array}$ & 63 \\
\hline 10 & $\begin{array}{l}\text { Fermentasi } \\
\text { roti tawar }\end{array}$ & Pemanggangan & 63 \\
\hline 11 & $\begin{array}{l}\text { Fermentasi } \\
\text { roti manis }\end{array}$ & Pemanggangan & 160 \\
\hline 12 & Pemanggangan & Pendinginan & 160 \\
\hline 13 & Pemanggangan & $\begin{array}{l}\text { Pengelupasan } \\
\text { Roti Tawar }\end{array}$ & 16 \\
\hline 14 & Pendinginan & $\begin{array}{l}\text { Pengemasan } \\
\text { roti manis }\end{array}$ & 160 \\
\hline 15 & $\begin{array}{l}\text { Rak loyang roti } \\
\text { tawar }\end{array}$ & $\begin{array}{l}\text { Pembentukan } \\
\text { roti tawar }\end{array}$ & 63 \\
\hline
\end{tabular}


Nabila Aulia Gunanti, Ade Momon .S dkk. Optimasi Tata Letak Fasilitas Menggunakan Algoritma Blocplan dan Corelap

\begin{tabular}{clll}
\hline No & Stasiun Awal & Stasiun Tujuan & Freq. \\
\hline 16 & $\begin{array}{l}\text { Pengelupasan } \\
\text { Roti Tawar }\end{array}$ & $\begin{array}{l}\text { Pengemasan } \\
\text { Roti Tawar }\end{array}$ & 16 \\
17 & $\begin{array}{l}\text { Pengemasan } \\
\text { Gudi Tawar }\end{array}$ & 3 \\
18 & $\begin{array}{l}\text { Pengemasan roti } \\
\text { roti manis }\end{array}$ & Gudang roti & 6 \\
\hline
\end{tabular}

\section{Jarak pada Tata Letak Awal}

Tabel 5 menunjukkan jarak antar stasiun kerja atau fasilitas pada tata letak awal.

\section{Tabel 5. Jarak pada Tata Letak Awal}

\begin{tabular}{|c|c|c|c|}
\hline No & Stasiun Awal & Stasiun Tujuan & $\begin{array}{c}\text { Jarak } \\
(\mathrm{m})\end{array}$ \\
\hline 1 & Gudang bahan baku & Mixing & 8,83 \\
\hline 2 & Gudang bahan baku & $\begin{array}{l}\text { Pembentukan } \\
\text { roti manis }\end{array}$ & 14,33 \\
\hline 3 & $\begin{array}{l}\text { Area penyimpanan } \\
\text { tepung }\end{array}$ & Mixing & 4,55 \\
\hline 4 & Mixing & Dough dividing & 4,12 \\
\hline 5 & Mixing & $\begin{array}{l}\text { Fermentasi roti } \\
\text { tawar }\end{array}$ & 13,57 \\
\hline 6 & Mixing & $\begin{array}{l}\text { Pembentukan } \\
\text { roti manis }\end{array}$ & 7,22 \\
\hline 7 & $\begin{array}{l}\text { Pembentukan roti } \\
\text { manis }\end{array}$ & $\begin{array}{l}\text { Fermentasi roti } \\
\text { manis }\end{array}$ & 7,1 \\
\hline 8 & $\begin{array}{l}\text { Fermentasi roti } \\
\text { tawar }\end{array}$ & $\begin{array}{l}\text { Pembentukan } \\
\text { roti tawar }\end{array}$ & 5,58 \\
\hline 9 & $\begin{array}{l}\text { Pembentukan roti } \\
\text { tawar }\end{array}$ & $\begin{array}{l}\text { Fermentasi roti } \\
\text { tawar }\end{array}$ & 5,58 \\
\hline 10 & $\begin{array}{l}\text { Fermentasi roti } \\
\text { tawar }\end{array}$ & Pemanggangan & 3,3 \\
\hline 11 & $\begin{array}{l}\text { Fermentasi roti } \\
\text { manis }\end{array}$ & Pemanggangan & 7,36 \\
\hline 12 & Pemanggangan & Pendinginan & 6,24 \\
\hline 13 & Pemanggangan & $\begin{array}{l}\text { Pengelupasan } \\
\text { Roti Tawar }\end{array}$ & 19,28 \\
\hline 14 & Pendinginan & $\begin{array}{l}\text { Pengemasan } \\
\text { roti manis }\end{array}$ & 5,71 \\
\hline 15 & $\begin{array}{l}\text { Rak loyang roti } \\
\text { tawar }\end{array}$ & $\begin{array}{l}\text { Pembentukan } \\
\text { roti tawar }\end{array}$ & 7,12 \\
\hline 16 & $\begin{array}{l}\text { Pengelupasan Roti } \\
\text { Tawar }\end{array}$ & $\begin{array}{l}\text { Pengemasan } \\
\text { Roti Tawar }\end{array}$ & 7,22 \\
\hline 17 & $\begin{array}{l}\text { Pengemasan Roti } \\
\text { Tawar }\end{array}$ & Gudang roti & 8,52 \\
\hline 18 & $\begin{array}{l}\text { Pengemasan roti } \\
\text { manis }\end{array}$ & Gudang roti & 7,71 \\
\hline
\end{tabular}

\section{Momen Perpindahan Awal}

Momen perpindahan material per hari pada tata letak awal ditunjukkan pada Tabel 6.

Tabel 6. Momen Perpindahan Awal

\begin{tabular}{|c|c|c|c|}
\hline No & Stasiun Awal & Stasiun Tujuan & $\begin{array}{l}\text { Momen } \\
(\mathrm{m} / \text { day })\end{array}$ \\
\hline 1 & $\begin{array}{l}\text { Gudang bahan } \\
\text { baku }\end{array}$ & Mixing & 114,79 \\
\hline 2 & $\begin{array}{l}\text { Gudang bahan } \\
\text { baku }\end{array}$ & $\begin{array}{l}\text { Pembentukan } \\
\text { roti manis }\end{array}$ & 71,65 \\
\hline 3 & $\begin{array}{l}\text { Area } \\
\text { penyimpanan } \\
\text { tepung }\end{array}$ & Mixing & 113,75 \\
\hline 4 & Mixing & Dough dividing & 222,48 \\
\hline 5 & Mixing & $\begin{array}{l}\text { Fermentasi } \\
\text { roti tawar }\end{array}$ & 298,54 \\
\hline 6 & Mixing & $\begin{array}{l}\text { Pembentukan } \\
\text { roti manis }\end{array}$ & 1660,6 \\
\hline 7 & $\begin{array}{l}\text { Pembentukan } \\
\text { roti manis }\end{array}$ & $\begin{array}{l}\text { Fermentasi } \\
\text { roti manis }\end{array}$ & 1136 \\
\hline 8 & $\begin{array}{l}\text { Fermentasi } \\
\text { roti tawar }\end{array}$ & $\begin{array}{l}\text { Pembentukan } \\
\text { roti tawar }\end{array}$ & 122,76 \\
\hline 9 & $\begin{array}{l}\text { Pembentukan } \\
\text { roti tawar }\end{array}$ & $\begin{array}{l}\text { Fermentasi } \\
\text { roti tawar }\end{array}$ & 351,54 \\
\hline 10 & $\begin{array}{l}\text { Fermentasi } \\
\text { roti tawar }\end{array}$ & Pemanggangan & 207,9 \\
\hline 11 & $\begin{array}{l}\text { Fermentasi } \\
\text { roti manis }\end{array}$ & Pemanggangan & 1177,6 \\
\hline 12 & Pemanggangan & Pendinginan & 998,4 \\
\hline 13 & Pemanggangan & $\begin{array}{l}\text { Pengelupasan } \\
\text { Roti Tawar }\end{array}$ & 308,48 \\
\hline 14 & Pendinginan & $\begin{array}{l}\text { Pengemasan } \\
\text { roti manis }\end{array}$ & 913,6 \\
\hline 15 & $\begin{array}{l}\text { Rak loyang roti } \\
\text { tawar }\end{array}$ & $\begin{array}{l}\text { Pembentukan } \\
\text { roti tawar }\end{array}$ & 448,56 \\
\hline 16 & $\begin{array}{l}\text { Pengelupasan } \\
\text { Roti Tawar }\end{array}$ & $\begin{array}{l}\text { Pengemasan } \\
\text { Roti Tawar }\end{array}$ & 115,52 \\
\hline 17 & $\begin{array}{l}\text { Pengemasan } \\
\text { Roti Tawar }\end{array}$ & Gudang roti & 25,56 \\
\hline \multirow[t]{2}{*}{18} & $\begin{array}{l}\text { Pengemasan } \\
\text { roti manis }\end{array}$ & Gudang roti & 46,26 \\
\hline & & Total & 8333,99 \\
\hline
\end{tabular}

\section{Ongkos Material Handling Awal}

Diketahui upah pegawai rata-rata per hari sebesar Rp70.000, dengan total jam kerja 12 jam per hari, dan jenis material 
handling yang digunakan adalah manual (tenaga manusia). Setiap perjalanan 1 meter setara dengan 3,28 kaki atau memerlukan 3-4 langkah. Pada metode MOST, 3-4 langkah dikategorikan ke dalam indeks A6 dengan bilangan indeks 6 TMU (Astuti \& Iftadi, 2016). Sehingga diperoleh $\mathrm{OMH}$ per meter sebesar Rp3,50/meter. Adapun $\mathrm{OMH}$ yang diakibatkan setiap perpindahan material per hari dapat dilihat pada Tabel 7 .

\section{Tabel 7. OMH Awal}

\begin{tabular}{|c|c|c|c|}
\hline No & Stasiun Awal & Stasiun Tujuan & OMH (Rp) \\
\hline 1 & $\begin{array}{l}\text { Gudang bahan } \\
\text { baku }\end{array}$ & Mixing & 401,77 \\
\hline 2 & $\begin{array}{l}\text { Gudang bahan } \\
\text { baku }\end{array}$ & $\begin{array}{l}\text { Pembentukan } \\
\text { roti manis }\end{array}$ & 250,78 \\
\hline 3 & $\begin{array}{l}\text { Area } \\
\text { penyimpanan } \\
\text { tepung }\end{array}$ & Mixing & 398,13 \\
\hline 4 & Mixing & Dough dividing & 778,68 \\
\hline 5 & Mixing & $\begin{array}{l}\text { Fermentasi roti } \\
\text { tawar }\end{array}$ & $1.044,89$ \\
\hline 6 & Mixing & $\begin{array}{l}\text { Pembentukan } \\
\text { roti manis }\end{array}$ & $5.812,10$ \\
\hline 7 & $\begin{array}{l}\text { Pembentukan } \\
\text { roti manis }\end{array}$ & $\begin{array}{l}\text { Fermentasi roti } \\
\text { manis }\end{array}$ & $3.976,00$ \\
\hline 8 & $\begin{array}{l}\text { Fermentasi roti } \\
\text { tawar }\end{array}$ & $\begin{array}{l}\text { Pembentukan } \\
\text { roti tawar }\end{array}$ & 429,66 \\
\hline 9 & $\begin{array}{l}\text { Pembentukan } \\
\text { roti tawar }\end{array}$ & $\begin{array}{l}\text { Fermentasi roti } \\
\text { tawar }\end{array}$ & $1.230,39$ \\
\hline 10 & $\begin{array}{l}\text { Fermentasi roti } \\
\text { tawar }\end{array}$ & Pemanggangan & 727,65 \\
\hline 11 & $\begin{array}{l}\text { Fermentasi roti } \\
\text { manis }\end{array}$ & Pemanggangan & $4.121,60$ \\
\hline 12 & Pemanggangan & Pendinginan & $3.494,40$ \\
\hline 13 & Pemanggangan & $\begin{array}{l}\text { Pengelupasan } \\
\text { Roti Tawar }\end{array}$ & $1.079,68$ \\
\hline 14 & Pendinginan & $\begin{array}{l}\text { Pengemasan } \\
\text { roti manis }\end{array}$ & $3.197,60$ \\
\hline 15 & $\begin{array}{l}\text { Rak loyang roti } \\
\text { tawar }\end{array}$ & $\begin{array}{l}\text { Pembentukan } \\
\text { roti tawar }\end{array}$ & $1.569,96$ \\
\hline 16 & $\begin{array}{l}\text { Pengelupasan } \\
\text { Roti Tawar }\end{array}$ & $\begin{array}{l}\text { Pengemasan } \\
\text { Roti Tawar }\end{array}$ & 404,32 \\
\hline 17 & $\begin{array}{l}\text { Pengemasan } \\
\text { Roti Tawar }\end{array}$ & Gudang roti & 89,46 \\
\hline 18 & $\begin{array}{l}\text { Pengemasan roti } \\
\text { manis }\end{array}$ & Gudang roti & 161,91 \\
\hline
\end{tabular}

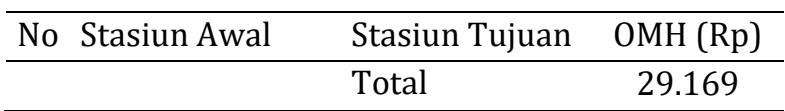

\section{Activity Relationship Chart}

Frekuensi perpindahan material terbanyak yaitu 230 kali per hari, sedangkan yang paling sedikit yaitu 3 kali perpindahan per hari.

Tabel 8. Nilai Derajat Kedekatan

\begin{tabular}{cc}
\hline Derajat Kedekatan & Frekuensi Perpindahan \\
\hline A & $155-230$ \\
E & $79-154$ \\
I & $3-78$ \\
\hline
\end{tabular}

Sumber: (Tarigan, 2012), (Afridasani, 2014)

dimodifikasi

Pada pengembangan tata letak usulan, area rak loyang roti tawar disatukan dengan stasiun pembentukan roti tawar untuk meminimalisir perpindahan yang dilakukan pegawai. ARC setelah penyesuaian fasilitas tersebut dapat dilihat pada Gambar 4.

\section{Kebutuhan Luas Lantai Fasilitas}

Tabel 4. Kebutuhan Luas Lantai

\begin{tabular}{clc}
\hline No & \multicolumn{1}{c}{ Fasilitas } & $\begin{array}{c}\text { Luas } \\
\left(\mathrm{m}^{2}\right)\end{array}$ \\
\hline 1 & Gudang bahan baku & 26 \\
2 & Penyimpanan Tepung & 8,1 \\
3 & Mixing & 18,9 \\
4 & Dough Dividing & 4,7 \\
5 & Pembentukan Roti Manis & 15,9 \\
6 & Fermentasi roti tawar & 10,7 \\
7 & Pembentukan Roti Tawar & 4,6 \\
8 & Fermentasi roti manis & 11,9 \\
9 & Pemanggangan & 34,0 \\
10 & Pendinginan & 4,0 \\
11 & Pengelupasan Roti Tawar & 24,6 \\
12 & Pengemasan roti tawar & 10,0 \\
13 & Pengemasan Roti Manis & 12,1 \\
14 & Gudang Roti & 15,9 \\
15 & Dapur & 17,2 \\
\hline Total & & 217,7 \\
\hline
\end{tabular}

Keterbatasan luas bangunan yang tersedia dioptimalkan pemanfaatannya 
Nabila Aulia Gunanti, Ade Momon .S dkk. Optimasi Tata Letak Fasilitas Menggunakan Algoritma Blocplan dan Corelap

karena kondisi tata letak awal tampak sesak, serta terdapat beberapa ruang kosong yang tidak terpakai. Hasil perhitungan kebutuhan luas lantai ditunjukkan pada Tabel 4.

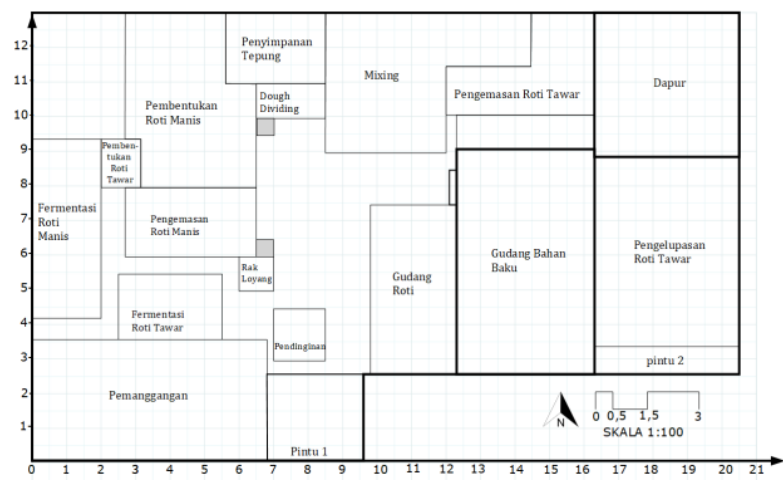

Gambar 3. Tata Letak Awal Pabrik Anni Bakery \& Cake

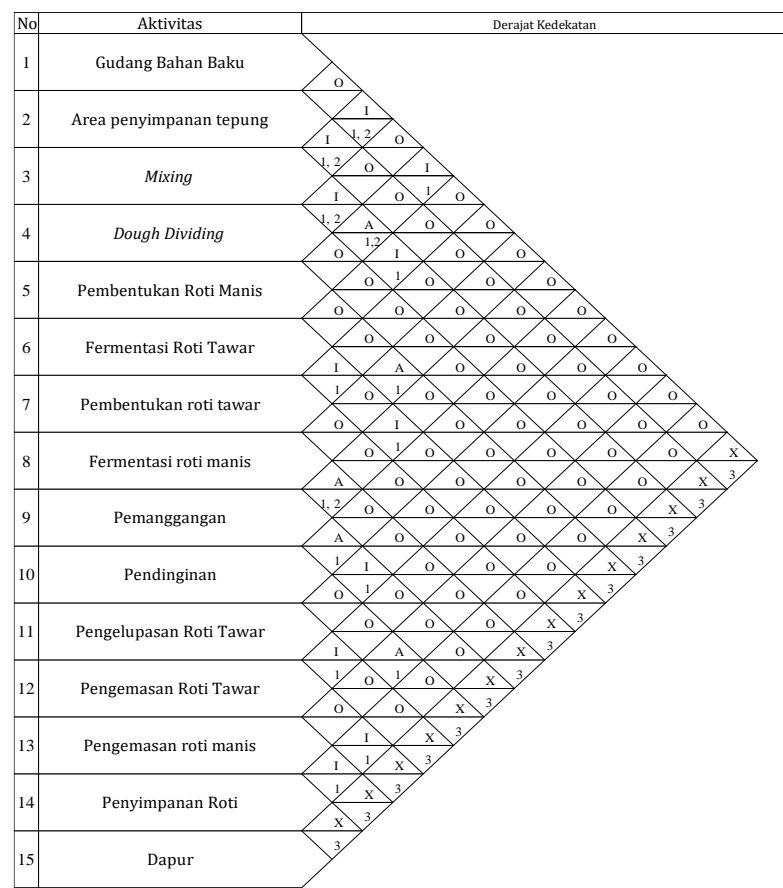

Gambar 4. Activity Relationship Chart (ARC)

\section{Tata Letak Algoritma BLOCPLAN}

Program

BLOCPLAN

mengembangkan 20 alternatif tata letak baru secara acak dalam sekali komputasi. Hasilnya dapat dilihat pada Tabel 5.

Tabel 5. Hasil Iterasi BLOCPLAN

\begin{tabular}{lllllll}
\hline $\begin{array}{l}\text { Lay } \\
\text { out }\end{array}$ & \multicolumn{2}{c}{ Adj-Score } & \multicolumn{2}{c}{ R-Score } & \multicolumn{2}{c}{$\begin{array}{c}\text { Rel Dist } \\
\text { Score }\end{array}$} \\
\hline 1 & 0.47 & -12 & 0.79 & -4 & 5116 & -10 \\
2 & 0.48 & -9 & 0.75 & -12 & 5236 & -15 \\
3 & 0.49 & -6 & 0.77 & -9 & 5094 & -8 \\
4 & 0.48 & -8 & 0.79 & -7 & 4436 & -1 \\
\hline 5 & 0.49 & -6 & 0.81 & -1 & 4725 & -2 \\
\hline 6 & 0.45 & -17 & 0.68 & -18 & 5127 & -11 \\
7 & 0.42 & -19 & 0.68 & -19 & 5841 & -20 \\
8 & 0.44 & -18 & 0.75 & -13 & 5287 & -17 \\
9 & 0.45 & -16 & 0.75 & -14 & 5075 & -7 \\
10 & 0.47 & -13 & 0.75 & -15 & 5114 & -9 \\
11 & 0.47 & -11 & 0.81 & -2 & 5132 & -12 \\
12 & 0.42 & -20 & 0.72 & -17 & 5203 & -14 \\
13 & 0.49 & -2 & 0.79 & -6 & 5382 & -19 \\
14 & 0.47 & -13 & 0.67 & -20 & 5336 & -18 \\
15 & 0.49 & -4 & 0.78 & -8 & 4931 & -3 \\
16 & 0.50 & -1 & 0.79 & -3 & 5143 & -13 \\
17 & 0.49 & -3 & 0.76 & -10 & 5068 & -5 \\
18 & 0.48 & -10 & 0.79 & -5 & 5253 & -16 \\
19 & 0.49 & -4 & 0.75 & -16 & 5014 & -4 \\
20 & 0.46 & -15 & 0.76 & -11 & 5070 & -6 \\
\hline
\end{tabular}

Tata letak yang optimal adalah yang memiliki adjacency score dan R-Score terbesar, serta rel-dist score terkecil. Alternatif tata letak yang memenuhi kriteria tersebut adalah tata letak ke-5, sehingga dipilih menjadi alternatif tata letak usulan. Detail alternatif terpilih dari algoritma BLOCPLAN ditunjukkan pada Gambar 5. Pada tata letak tersebut telah dilakukan penyesuaian secara manual untuk mengalokasikan gang dengan lebar $1 \mathrm{~m}$ dengan menggunakan sekitar 25\% dari seluruh luas fasilitas (Apple, 2016). Selain itu, sisa ketersediaan ruang digunakan untuk penambahan fasilitas toilet.

\section{Tata Letak Algoritma CORELAP}

Tabel 6 menunjukkan hasil perhitungan TCR pada setiap fasilitas atau 
stasiun kerja. Stasiun pemanggangan memiliki nilai TCR tertinggi, sehingga ditempatkan pertama di pusat kegiatan sesuai aturan pada algoritma CORELAP.

Tabel 6. Total Closeness Rating

\begin{tabular}{llc}
\hline No & Fasilitas & TCR \\
\hline 1 & Gudang bahan baku & 28 \\
2 & Penyimpanan Tepung & 24 \\
3 & Mixing & 64 \\
4 & Dough Dividing & 24
\end{tabular}

\begin{tabular}{llc}
\hline No & Fasilitas & TCR \\
\hline 5 & Pembentukan Roti Manis & 80 \\
6 & Fermentasi roti tawar & 32 \\
7 & Pembentukan Roti Tawar & 24 \\
8 & Fermentasi roti manis & 76 \\
\hline 9 & Pemanggangan & 84 \\
\hline 10 & Pendinginan & 76 \\
11 & Pengelupasan Roti Tawar & 28 \\
12 & Pengemasan roti tawar & 28 \\
13 & Pengemasan Roti Manis & 52 \\
14 & Gudang Roti & 28 \\
15 & Dapur & -448 \\
\hline
\end{tabular}

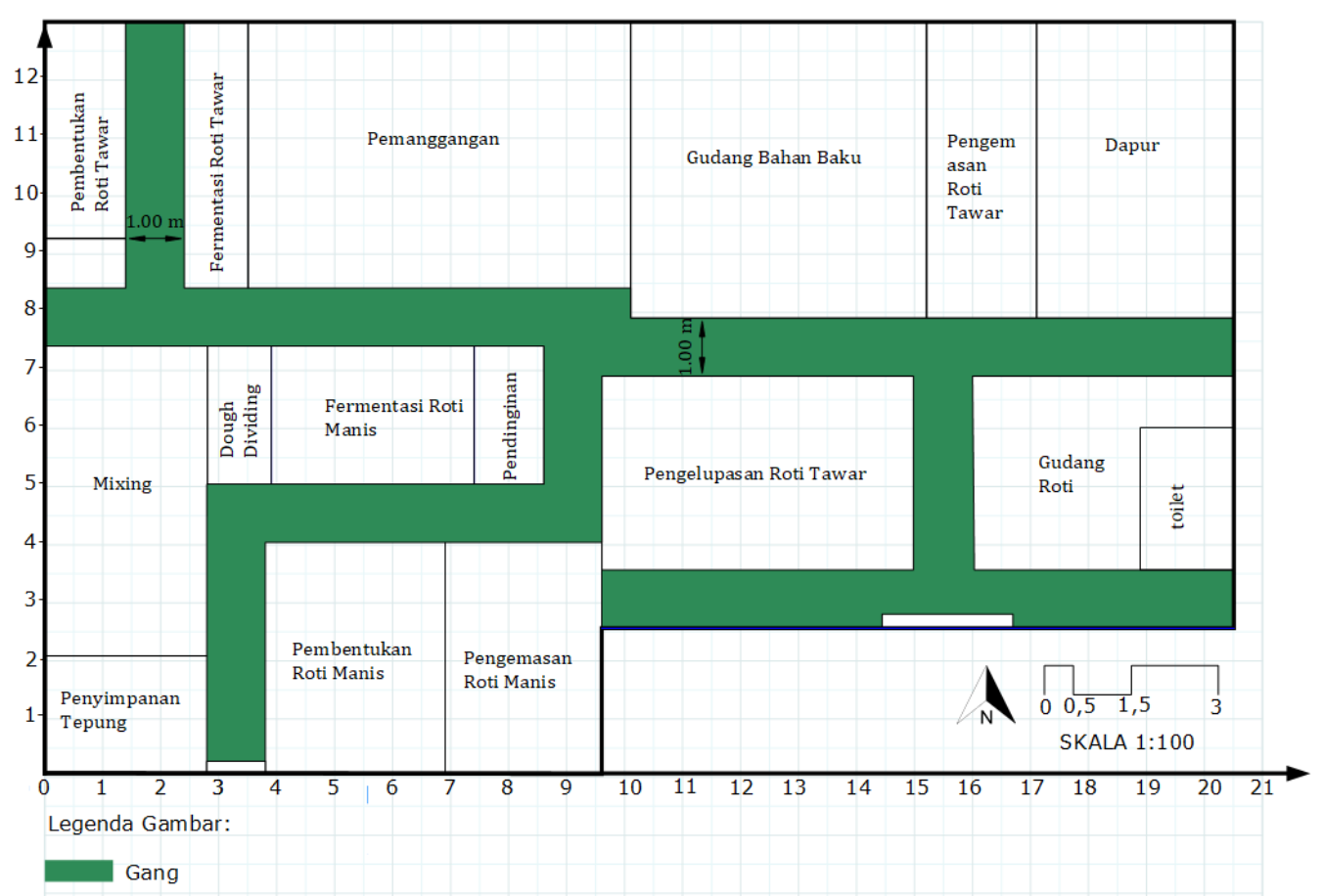

Gambar 5. Alternatif Tata Letak Usulan Algoritma BLOCPLAN

Adapun hasil tata letak yang yang sama dengan tata letak BLOCPLAN dihasilkan oleh Algoritma CORELAP dapat yaitu alokasi gang dan penambahan dilihat pada Gambar 6. Pada tata letak fasilitas toilet. tersebut juga telah dilakukan penyesuaian 
Nabila Aulia Gunanti, Ade Momon .S dkk. Optimasi Tata Letak Fasilitas Menggunakan Algoritma Blocplan dan Corelap

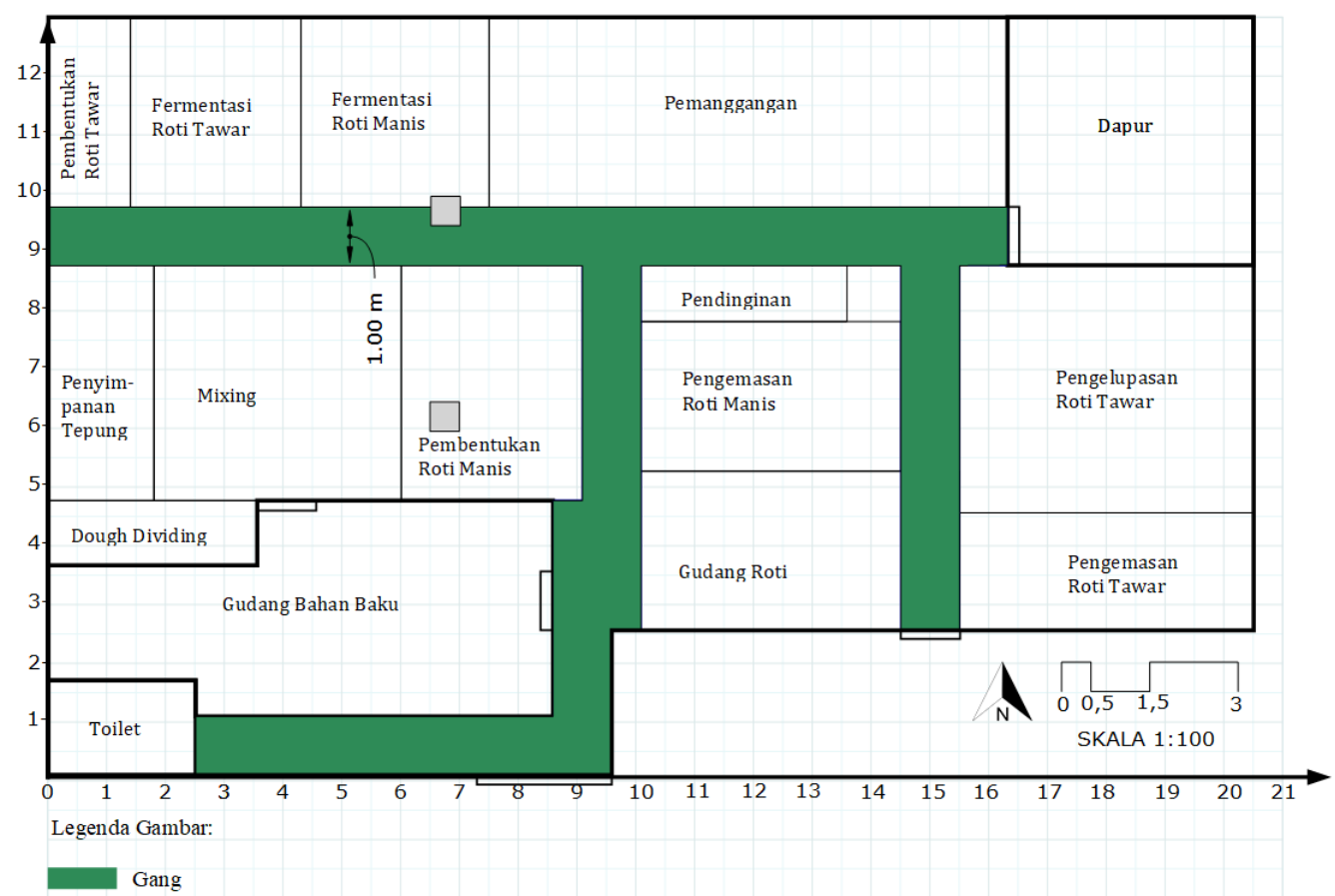

Gambar 6. Alternatif Tata Letak Usulan Algoritma CORELAP

\section{Pemilihan Tata Letak Usulan}

Performansi tata letak hasil algoritma BLOCPLAN dan CORELAP dibandingkan dengan tata letak awal.

Tabel 7 menunjukkan perbandingan momen perpindahan (meter/hari), $\mathrm{OMH}$ (Rp/hari), dan efisiensi (\%) pada tata letak awal, BLOCPLAN, dan CORELAP.

Tabel 7. Perbandingan Momen, OMH, dan Efisiensi Tata Letak

\begin{tabular}{llll}
\hline & \multicolumn{3}{c}{ Tata Letak } \\
\cline { 2 - 4 } & Awal & BLOCPLAN & CORELAP \\
\hline Momen & $8.333,99$ & 6403 & 5321,65 \\
OMH & 29.169 & 22.410 & 18.626 \\
Efisiensi & - & 23,30 & 36,10 \\
\hline
\end{tabular}

Dari tabel tersebut dapat diketahui bahwa tata letak algoritma CORELAP paling unggul dalam memberikan momen perpindahan terkecil, $\mathrm{OMH}$ terkecil, dan efisiensi tata letak tertinggi. Sehingga, rancangan tata letak CORELAP dipilih menjadi tata letak yang diusulkan untuk memperbaiki kondisi tata letak saat ini.
Konsep algoritma BLOCPLAN yang melakukan penempatan fasilitas secara acak dapat menjadi alasan kurang efisiennya tata letak yang dihasilkan. BLOCPLAN memerlukan iterasi puluhan kali atau sesuai keberuntungan untuk mendapatkan efisiensi tata letak yang maksimal. Prinsip algoritma CORELAP yang menempatkan fasilitas berdasarkan nilai TCR terbesar terbukti lebih unggul dalam mengatasi permasalahan tata letak pada ini,

\section{Perubahan Pola Aliran Material}

Aliran material pada tata letak awal berbentuk tidak beraturan akibat kurangnya perencanaan tata letak, hal ini terlihat dari Gambar 7 yang menunjukkan ketidakteraturan perpindahan material di lantai produksi. Namun setelah dilakukan perancangan ulang maka diperoleh perubahan keteraturan aliran material dengan pola zig-zag yang ditunjukkan pada Gambar 8. 
Secara teoritis, perubahan pola aliran meminimalisir kecelakaan kerja, yang terencana ini akan memberikan mengurangi kemacetan lalu-lintas gang, keuntungan antara lain: menaikkan mengurangi kerusakan produk, dan produktivitas, mengurangi waktu dalam mengurangi jarak jalan kaki oleh operator proses, mengurangi waktu menganggur, (Apple, 2016):

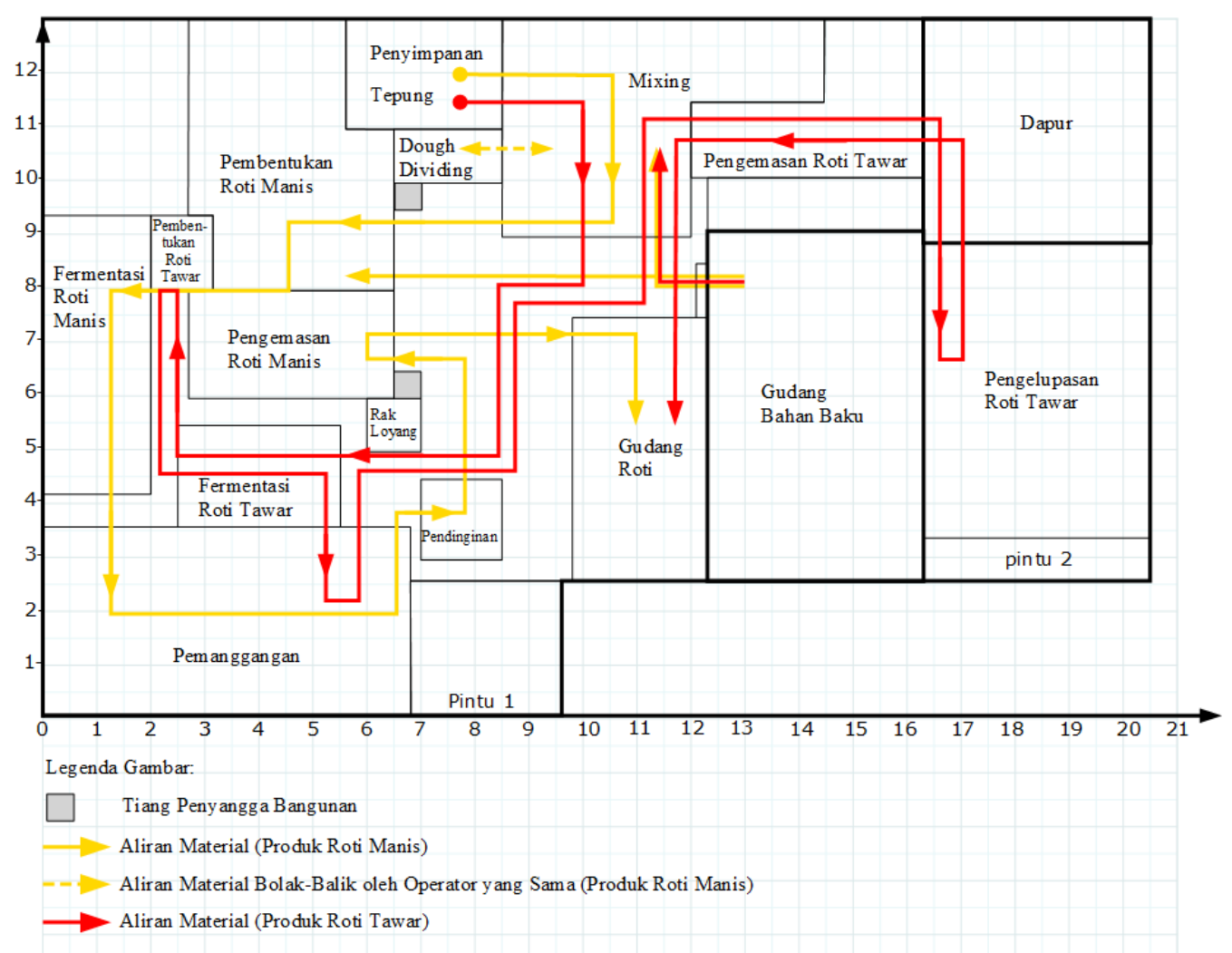

Gambar 7. Pola Aliran Material pada Tata Letak Awal 
Nabila Aulia Gunanti, Ade Momon .S dkk. Optimasi Tata Letak Fasilitas Menggunakan Algoritma Blocplan dan Corelap

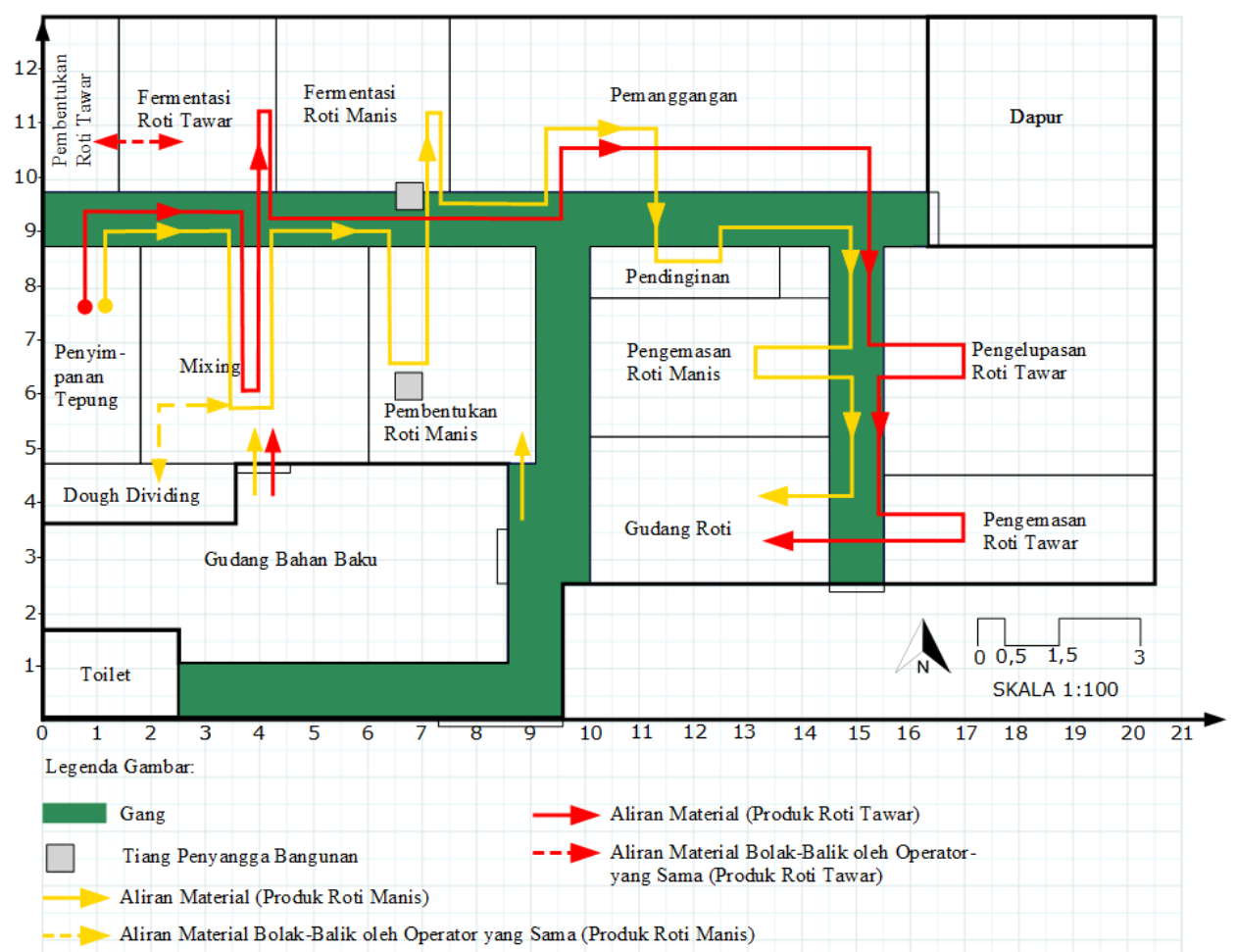

Gambar 8. Pola Aliran Material pada Tata Letak Usulan Terpilih (CORELAP)

\section{Kelebihan Tata Letak Usulan}

Tabel 8. Kelebihan Tata Letak Usulan

\begin{tabular}{|c|c|c|}
\hline No & Tata Letak Awal & Tata Letak Usulan \\
\hline 1 & $\begin{array}{l}\text { Pabrik terdiri dari } 1 \text { bangunan yang memiliki } \\
\text { luas } 230,85 \mathrm{~m}^{2} \text {. }\end{array}$ & $\begin{array}{l}\text { Perbaikan tata letak mengoptimalkan luas } \\
\text { bangunan saat ini, tanpa merubah bentuk } \\
\text { bangunan. }\end{array}$ \\
\hline 2 & $\begin{array}{l}\text { Jarak perpindahan material yang paling } \\
\text { besar yaitu pada proses pemanggangan ke } \\
\text { proses pengelupasan roti tawar. Kedua } \\
\text { stasiun tersebut memiliki hubungan } \\
\text { kerterkaitan langsung namun diletakkan } \\
\text { saling berjauhan dengan jarak } 19,28 \mathrm{~m} \text {. }\end{array}$ & $\begin{array}{l}\text { Stasiun pemanggangan ke stasiun pengelupasan } \\
\text { roti tawar dibuat berdekatan dengan jarak 10,82 } \\
\mathrm{m} \text {, atau menghemat perjalanan hingga } 8,46 \mathrm{~m} \text { tiap } \\
\text { perpindahan material dibandingkan dengan tata } \\
\text { letak awal. }\end{array}$ \\
\hline 3 & $\begin{array}{l}\text { Terdapat aliran backtracking pada proses } \\
\text { pengelupasan roti tawar ke proses } \\
\text { pengemasan roti tawar }\end{array}$ & $\begin{array}{l}\text { Aliran backtracking pada proses pengelupasan roti } \\
\text { tawar ke proses pengemasan dihilangkan. }\end{array}$ \\
\hline 4 & $\begin{array}{l}\text { Terdapat aliran pemindahan material yang } \\
\text { berpotongan (cross movement) antar stasiun } \\
\text { kerja dikarenakan tidak adanya jalur khusus } \\
\text { untuk perpindahan material. }\end{array}$ & $\begin{array}{l}\text { Space untuk gang dialokasikan pada tata letak } \\
\text { berserta penanda gang yang dibuat formal sebagai } \\
\text { jalur perpindahan material untuk menghilangkan } \\
\text { cross movement. }\end{array}$ \\
\hline 5 & $\begin{array}{l}\text { Pintu masuk dan keluar terhalang oleh } \\
\text { bakery trolley pada proses pendinginan. }\end{array}$ & $\begin{array}{l}\text { Pintu masuk dan keluar dibuat lurus sejajar } \\
\text { dengan gang, dan posisi stasiun pendinginan } \\
\text { dipindahkan, }\end{array}$ \\
\hline 6 & $\begin{array}{l}\text { Tidak ada toilet sebagai fasilitas pelayanan } \\
\text { personel. }\end{array}$ & $\begin{array}{l}2 \text { buah toilet tersedia dengan pertimbangan } \\
\text { penempatannya sedemikian rupa agar tidak } \\
\text { memepengaruhi higienitas proses produksi. }\end{array}$ \\
\hline
\end{tabular}




\section{SIMPULAN}

Dua model tata letak yang diusulkan berdasarkan algoritma BLOCPLAN dan CORELAP dibandingkan dalam penelitian ini. Berdasarkan beberapa kriteria pembanding yaitu momen perpindahan minimum, ongkos material handling minimum, dan efisiensi tata letak tertinggi, hasilnya menunjukkan bahwa tata letak CORELAP dipilih sebagai tata letak usulan karena kemampuannya memberikan tata letak yang lebih optimal. CORELAP menghasilkan momen perpindahan sebesar 5.321,65 $\mathrm{m}$ /hari dengan efisiensi tata letak $36,10 \%$, serta ongkos material handling sebesar Rp18.626/hari. Tata letak yang diusulkan meningkatkan pemanfaatan ruang yang tersedia, menambahkan gang untuk memudahkan pemindahan material, dan penambahan fasilitas pegawai berupa toilet, tanpa memerlukan perubahan bentuk awal bangunan.

\section{DAFTAR PUSTAKA}

Adiyanto, O., \& Clistia, A. F. (2020). Perancangan Ulang Tata Letak Fasilitas Produksi UKM Eko Bubut dengan Metode Computerized Relationship Layout Planning (CORELAP). Jurnal Integrasi Sistem Industri, 7(1), 49-56.

Afridasani, N. (2014). Perancangan Ulang Tata Letak Fasilitas Produksi Dengan Menerapkan Travel Chart, Algoritma BLOCPLAN dan CORELAP di PT. Cahaya Bintang Medan. Universitas Sumatera Utara.

Apple, J. M. (2016). Tata Letak Pabrik dan Pemindahan Bahan (I. Z. Sutalaksana (ed.); 3rd ed.). ITB Press.

Astuti, R. D., \& Iftadi, I. (2016). Analisis dan Perancangan Sistem Kerja (1st ed.). Deepublish.

Dwianto, Q. A., Susanty, S., \& Fitria, L. (2016). Usulan Rancangan Tata Letak Fasilitas Dengan Menggunakan Metode Computerized Relationship Layout Planning (CORELAP) Di Perusahaan Konveksi. Jurnal Online Institut Teknologi Nasional, 04(01), 87-97.
Febianti, E., Kulsum, \& Pradifta, D. (2020). Relayout Gudang Bahan Baku dengan Menggunakan Metode CORELAP dan CRAFT di PT. XYZ. Journal Industrial Servicess, 6(1).

Gunawan, J. W., Octavia, T., \& Felecia. (2015). Perancangan tata letak fasilitas pada PT. Lima Jaya. Jurnal Titra, 3(2), 195-202.

Heragu, S. S. (2006). Facilities Design (2nd ed.). iUniverse.

https://books.google.co.id/books?id=GTwPZ 1RNS-

UC\&newbks=0\&printsec $=$ frontcover $\& p g=P A$ $197 \& d q=$ CORELAP \&hl=id\&source=newbks_f b\&redir_esc $=y \# v=$ onepage $\& \mathrm{q}=$ CORELAP $\& \mathrm{f}=\mathrm{f}$ alse

Ignasius, A. (2017). Perancangan Ulang Tata Letak Pabrik dengan Menggunakan Algoritma BLOCPLAN dan Algoritma CORELAP pada PT. Aroma Mega Sari. Universitas Sumatera Utara.

Iskandar, N. M., \& Fahin, I. S. (2017). Perancangan Tata Letak Fasilitas Ulang (Relayout) Untuk Produksi Truk Di Gedung Commercial Vehicle (Cv) Pt. Mercedes- Benz Indonesia. Jurnal PASTI, XI(1), 66-75.

Langgihadi, D., Bakar, A., \& Susanty, S. (2016). Usulan Rancangan Ulang Tata Letak Fasilitas Dengan Menggunakan Metode Computerized Relationship Layout Planning (CORELAP) Di Perusahaan Distribusi Bahan Bakar Pesawat Udara. Jurnal Online Institut Teknologi Nasional, 4(1), 279.

Putra, Y. P. (2018). Merancang tata letak fasilitas pabrik dengan metode algoritma corelap di CV. Robbani Singosari. Jurnal Valtech, 1(1), 65-70.

https://ejournal.itn.ac.id/index.php/valtech /article/view/92

Richardo, V., Santoso, D. A., \& Talitha, T. (2017). Minimasi Jarak Perpindahan Material Menggunaan Algoritma Blocplan dalam Perancangan Tata Letak Proses Produksi Produk Vulkanisir Ban. Applied Industrial Engineering Journal, 1(1), 39-46.

Setiyawan, D. T., Hadlirotul Qudsiyyah, D., \& Asmaul Mustaniroh, S. (2017). Improvement of Production Facility Layout of Fried Soybean using BLOCPLAN and CORELAP Method (A Case Study in UKM MMM Gading Kulon, Malang). Industria: Jurnal Teknologi Dan Manajemen Agroindustri, 6(1), 51-60. https://doi.org/10.21776/ub.industria.2017 .006 .01 .7

Siregar, R. M., Sukatendel, D., Tarigan, U., Industri, D. T., Teknik, F., Utara, U. S., \& Handling, M. (2013). Perancangan Ulang Tataletak Fasilitas Produksi Dengan Menerapkan Algoritma Blocplan Dan Algoritma Corelap Pada Pt. Xyz. Jurnal Teknik Industri USU, 1(1), 
Nabila Aulia Gunanti, Ade Momon .S dkk. Optimasi Tata Letak Fasilitas Menggunakan Algoritma Blocplan dan Corelap

35-44.

Susetyo, J., Simanjutak, R. A., \& Ramos, J. M. (2010). Perancangan Ulang Tata Letak Fasilitas Produksi Dengan Pendekatan Group Technology Dan Algoritma BLOCPLAN Untuk Meminimasi Ongkos Material Handling. Jurnal Teknologi, 3(Juni), 75-83.

Sutrisno, T. (2017). Kerja Fisik Terhadap Produktivitas Kerja Karyawan Bagian Produksi ( studi pada PT . Unilever Indonesia, Tbk TBB Factory ). Sekolah Tinggi Ilmu Ekonomi Pelita Bangsa.

Tambunan, M., Ginting, E., \& Sari, R. M. (2018). Production facility layout by comparing moment displacement using BLOCPLAN and ALDEP Algorithms. IOP Conference Series: Materials Science and Engineering, 309(1). https://doi.org/10.1088/1757-

899X/309/1/012032
Tarigan, R. A. A. (2012). Perancangan ulang tataletak fasilitas produksi dengan algoritma blocplan dan algoritma craft di cv. abc hardware industry tugas sarjana. Universitas Sumatera Utara.

Tarigan, U., Tarigan, U. P. P., \& Dalimunthe, Z. A. (2017). Aplikasi Algoritma Block Plan dan ALDEP dalam Perancangan Ulang Tata Letak Fasilitas Produksi Pabrik Pengolahan Karet. Seminar Nasional Teknik Industri [SNTI2017, September, 313-322.

Polewangi, Y.D, Kusumawaty, D (2020). Perancangan Tata Letak Fasilitas Laboratorium Kalibrasi. Jurnal Teknik dan Teknologi 15(29),27-35.

Polewangi, Y.D, Sinulingga, S, Nazaruddin, N (2015). Perencanaan Ulang Layout dalam Upaya Peningkatan Utilisasi Kapasitas. Industrial Engineering Journal 4(1). 